\title{
Participation in sports and sociometric status of adolescents
}

\author{
Aleksandar Gadžić ${ }^{1}$, Igor Vučković 2 \\ ${ }^{1}$ Academy of Football Belgrade, Serbia, ${ }^{2}$ Faculty of Physical Education and Sport, University in Banja Luka, \\ Bosnia and Herzegovina
}

\begin{abstract}
Summary
Study aim: To examine the relationships between sport participation and sociometric status of adolescent youths. Material and methods: A group of 359 secondary school students from central Serbia (143 male and 216 female) aged $16-19$ years participated in the study. The subjects were given questionnaires pertaining to their participation in sports and sociometric relations, especially "work with" and "interact with".

Results: In total, about $23 \%$ of subjects were actively engaged in sports at various levels: local (11\%), regional $(8 \%)$, national $(3 \%)$ and international $(2$ subjects), the others were classified as sedentary. The sport-active subjects scored significantly $(\mathrm{p}<0.001)$ higher sociometric acceptance and sociometric status and lower sociometric rejection $(\mathrm{p}<0.05)$ than the sedentary ones. However, no significant correlations were found between sport-engagement variables and the sociometric ones.

Conclusions: The presented results can be regarded as preliminary only and call for conducting the study on a larger cohort and to include more psychosocial variables.
\end{abstract}

\section{Key words: $\quad$ Sport participation - Sociometric status - Adolescents}

\section{Introduction}

Participation of adolescents in sports is considered as contributing to a better sociometric status and acceptance by schoolmates. It is believed that sport helps to shape character, self-discipline and persistence, reflected in one's sociometric status. Numerous studies point out positive, enhancing effects of physical engagement and positive correlations between intellectual and motor abilities during adolescence $[1,13,16,22]$.

The relationships between extracurricular activities, such as sport participation and perception of sport and social competence, were the objective of many studies $[8,18]$; it was shown that sport participants had higher self-esteem, perception of sport and social competence and lower scores for anxiety/depression, etc., compared with their sedentary mates. These findings imply that children, who consider themselves successful in sports, are also so perceived by their peers. The importance of social competence among competitive athletes was confirmed by Vučković [19] who found that basketball players of the first league in Serbia and Montenegro, who had better social competence, were more successful as players. Sport activities require co-operation, support, understanding and sportsmanship; it is, therefore, logical to expect a transfer of these values to the social environment of sport participants. Some authors found significant relationships between sport participation, and peer acceptance $[9,15,20]$ and popularity $[4,10]$. Other authors suggested that sport participation contributed to social inclusion [2,21] and prosocial behaviour [12].

Among many factors which may contribute to the acceptance by schoolmates, athletic competence is probably the most important one, especially for younger children. Many satisfying interpersonal experiences can be gained through sport participation such as the formation of friendships, social affiliation, feeling part of a team and gaining approval from peers, hence it seems natural for young boys to be part of such experience. Specifically, both perception of personal efficacy and motivation are significantly and positively correlated with physical exercise [7]. Carlson et al. [3] found that 8 years after graduating from a secondary school, the athletes were more successful in continuing education and finding jobs than their sedentary mates. On the other hand, some authors reported negative effects of sport participation on social competence $[11,14]$, reflected in e.g. higher social exclusion [6]. It ought to be emphasised that these studies considered 
sport participation within school setting, while the objective of the present study is to examine students' participation in sports outside their school setting, and the sociometric status within it, focusing on social aspect of adolescence. The aim of the study was to assess the relationships between sport participation and sociometric status of adolescents at school and to compare those engaged in sports with their sedentary mates with respect to sociometric indices.

\section{Material and Methods}

Subjects: All studied subjects (143 male and 216 female), aged 16 - 19 years, attended one secondary school in central Serbia. Among them were 45 boys and 37 girls (23\% combined) who declared practicing sports, the remaining 98 boys and 179 girls being classified as sedentary. The criteria of sport engagement, based on the questionnaire (see below), were as follows: practising sports at least twice a week, at least one year of training experience and being listed as competitor in a sport team.

Methodology: The modified sport participation questionnaire of Gašić-Pavišić and Janjetović [14] was used to assess the sport participation variables. The questionnaire contained 5 questions pertaining to sport activities. The following sport engagement variables were recorded: training experience (years), competition level (1 - local, 2 - regional, 3 - national and 4 - international), training volume (training sessions per week).

Sociometric status via peer nominations [5] was determined by a questionnaire administered at the end of the school year; it was presumed that the school year lasted long enough to enable establishing interpersonal relationships. The subjects were asked to indicate their classmates whom they "most liked to work with" and "most liked to interact with", as well as those with whom they most disliked to work and to interact. Peer acceptance was defined as the ratio of most liked indications and peer rejection as the ratio of least liked indications to the total of potential indications. From those, sociometric indices were computed [17]: Index of Acceptance: $\mathrm{IOA}=\sum$ positive indications $/ 2(\mathrm{n}-1)$, Index of Rejection: IOR $=\sum$ negative indications $/ 2(n-1)$ and Index of Sociometric Status: ISS $=\left(\sum\right.$ positive indications $-\sum$ negative indications) / $2(\mathrm{n}-1)$.

Student's $t$-test for independent groups and Pearson's coefficients of correlation between sport participation and sociometric status variables were used. The level of $\mathrm{p} \leq 0.05$ was considered significant.

\section{Results}

The engagement in sports, defined as participation in competitions at various levels, is presented in Fig. 1 and mean values of studied variables in both groups of subjects - in Table 1 . The young athletes competed mainly at local and regional levels ( $85 \%$ combined) but two of them competed at international level. Their training experience ranged from 1 to 9 years, the numbers of training sessions per week ranging from 2 to 10 .

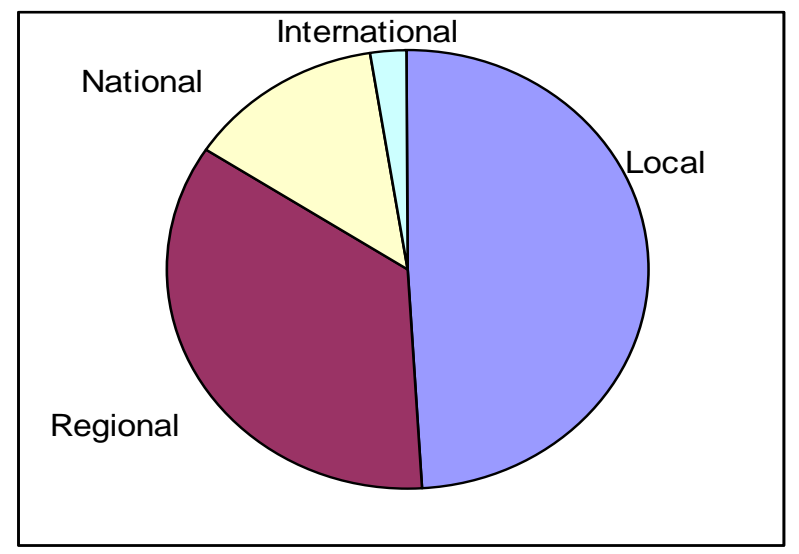

Fig. 1. Percent distribution of subjects engaged in sport competitions at various levels $(n=82)$

Table 1. Mean values ( \pm SD) of sport participation and sociometric variables in youths aged $16-19$ years, engaged or not in sport activities

\begin{tabular}{|c|c|c|}
\hline Variable & $\begin{array}{c}\text { Sport-active } \\
\mathrm{n}=82\end{array}$ & $\begin{array}{c}\text { Sedentary } \\
\mathrm{n}=277\end{array}$ \\
\hline Training experience & $5.62 \pm 2.41$ & - \\
\hline Competition level & $1.70 \pm 0.78$ & - \\
\hline Training volume & $4.00 \pm 1.77$ & - \\
\hline Index of acceptance & $0.15 \pm 0.09 * *$ & $0.12 \pm 0.07$ \\
\hline Index of rejection & $0.07 \pm 0.09 *$ & $0.10 \pm 0.12$ \\
\hline ISS & $0.08 \pm 0.14 * * *$ & $0.01 \pm 0.15$ \\
\hline
\end{tabular}

Legend: ISS - Index of sociometric status; Significantly different from the sedentary group: ${ }^{*} \mathrm{p}<0.05 ; * * \mathrm{p}<0.01 ; * * * \mathrm{p}<0.001$

Subjects from the sport-engaged group attained significantly higher sociometric acceptance $(p<0.01)$ and sociometric status $(p<0.001)$, and lower $(p<0.05)$ sociometric rejection than the sedentary group. However, none of the sport engagement variables correlated significantly with those of sociometric status, correlation coefficients ranging from -0.039 to 0.138 .

\section{Discussion}

Some reports consistently linked peer acceptance to sport participation $[9,15]$ and showed that children who exhibited athletic competence and high self-perceived athletic abilities tended to be more popular among their peers than the less skilled ones $[4,10,18,20]$. In this study, 
the within-school issues were extended to active participation in sport teams, by assessing the acceptance/rejection of sport-engaged subjects by their schoolmates. The fact that the studied cohort was fairly homogenous with respect to school environment and sociometric status might have been of importance. The obtained results were concordant with the abovementioned reports. However, no significant relationships between sociometric status and sport participation were found. It could be speculated that the higher sociometric status of the sport group was due to the mere engagement in sport activities, the specific sport achievements being of lower importance. Moreover, the fact that the subjects in study attended the same school limited possible generalisations. The measures used in this study ought to be expanded and include the issues of within-school sport participation and a broader range of psychosocial factors. Further studies would thus be needed to consider both within-school and outer factors contributing to the sport issue.

\section{References}

1. Bačanac Lj., Lj.Lazarević, A.Milojević (2001) The correlation of athletics simple and complex relation time with classic IQ tests. Proc.10th World Congr.Sport Psychol., Skiathos, Greece, Book 4:108-110.

2. Bailey R.P. (2004) Evaluating the relationship between physical education, sport and social inclusion. Educ.Rev. 56(3).

3. Carlson D., L.Scott, M.Planty, J.Thompson (2005) What is the status of high school athletes 8 years after their senior year? In: Statistics in brief, National Center for Education Statistics, U.S. Department of Education, Institute of Education Sciences NCES 2005, p.303.

4. Chase M.A., G.M.Dummer (1992) The role of sports as a social status determinant for children. Res.Q.Exerc.Sport 63: 418-424.

5 Coie J., K.Dodge, H.Coppotelli (1982) Dimensions and types of social status: A cross-age perspective. Dev.Psychol. 18:557-570.

6. Collins M., T.Kay (2003) Sport and Social Exclusion. Routledge, London.

7. Dishman, R.K., J.F.Sallis, D.R.Orenstien (1985) The determinants of physical activity and exercise. PublicHealthRep. 100:158-171.

8. Đonlić V., O.Marušić-Štimac, S.Smojver-Ažić (2005) Odgojni aspekti sporta - slika o sebi i problemna ponašanja obzirom na uključenost $\mathrm{i}$ uspješnost djece u sportskim aktivnostima [Educational aspects of Sports - Self-image and problematic Behavior reference Sport Participation and Success in Sport Activities]. Proc. 6th Sports Conf. Alpe-Jadran, Opatija, pp. 197-204.
9. Daniels E., C.Leaper (2006) A longitudinal investigation of sport participation, peer acceptance, and self-esteem among adolescent girls and boys. Sex Roles 55:11-12.

10. Eder D., D.A.Kinney (1995) The effect of middle school extracurricular activities on adolescents' popularity and peer status. Youth and Society 26:298-324.

11. Endersen I. M., D.Olweus (2005) Participation in power sports and antisocial involvement in preadolescent and adolescent boys. J.Child Psychol.Psychiatr. 46:468-478.

12. Gašić-Pavišić S., D. Janjetović (2007) Povezanost učešća u sportu sa prosocijalnom orijentacijom i agresijom adolescenata: razlike po polu [Connection between participation in sport and pro-social orientation and aggression of adolescents: genderrelated differences]. Zbornik Instituta za Pedagoška Istraživanja, 2:329-346

13. Gruber J.J., D.R.Kirkendall (1970) Canonical relationships between the motor and intellectual achievement domains in culturally deprived high school pupils. Res.Q. 41:496-502.

14. Kavussanu M., A.R.Seal, D.Philips (2006) Observed prosocial and antisocial behaviors in male soccer teams: age differences across adolescence and the role of motivational variables. J.Appl.SportPsychol. 18:326-344.

15. Lubbers M.J., M.Van Der Werf, H.Kuyper, G.J.Offringa (2006) Predicting peer acceptance in Dutch youth. J.Early Adolesc. 26:4-35.

16. Milojević A. (1996) Relacije intelektualnih i motoričkih sposobnosti u razvojnom periodu [Relationships between intellectual and motor abilities in the developmental period]. Zbornik Radova Filozofskog Fakulteta, Univerzitet u Prištini 1:90-107.

17. Proctor C.H., C.P.Loomis (1957) Analysis of sociometric data. In: M.Jahoda, M.Deutsch, S.W.Cook (eds.) Research Methods in Social Relations. Dryden Press,New York, pp. 2562.

18. Rose B., D.Larkin, B.G.Berger (1997) Coordination and gender influences on the perceived competence of children. Adapted Phys.Act.Q. 14:63-71.

19. Vučković I. (2004) Razlike između boljeplasiranih i lošijeplasiranih rimova I коšarkaške lige Srbije i Crne Gore u nekim sociološkim faktorima [Differences between higher and lower ranked teams of the first basketball league of Serbia and Montenegro in some sociological characteristics]. M.S. thesis. Faculty of Physical Education, Novi Sad University, Serbia.

20. Weiss M.R., S.C.Duncan (1992) The relation between physical competence and peer acceptance in the context of children's sport participation. J.Sport Exerc.Psychol. 14:177-191.

21. Weiss M.R., B.J.Bredemeier (1990) Moral development in sport. In: K.R.Pandolf, J.O.Hollowszy (eds.) Exercise and Sport Sciences Reviews, Vol. 18, Williams and Wilkins, Baltimore, MD.

22. Wilson G.D., O.A.Tunstall, H.J.Eysenck (1971) Individual differences in tapping performance as a function of time on the task. Percept.Motor Skills 33:375-378.

\section{Received 11.05.2009}

Accepted 12.10.2009

(C) University of Physical Education, Warsaw, Poland 